\title{
JURNALIS DALAM TINJAUAN SOSIAL EKONOMI POLITIK PADA KONFLIK SUNNI-SYIAH DI KABUPATEN SAMPANG
}

\author{
Abd Aziz \& Matnin \\ Fakultas Ilmu Sosial Politik (FISIP) UNAIR Surabaya \\ IAI Al-Khairat Pamekasan \\ Email: abdaziz.madura@gmail.com
}

\begin{abstract}
Abstrak
Pemberitaan hasil liputan wartawan mengenai konflik bernuansa Sara antara kelompok Islam Syiah dan kelompok Islam Sunni yang terjadi di Sampang Madura Jawa Timur pada 26 Agustus 2012 telah menyebabkan satu orang meninggal, dan enam orang lainnya luka-luka, serta sebanyak 47 rumah warga Syiah ludes dibakar kelompok penyerang. Sedikitnya 282 warga Syiah di Desa Karang Gayam, Kecamatan Omben, dan Desa Blu'uran, Kecamatan Karangpenang, Sampang harus dievakuasi akibat konflik berdarah tersebut. Studi ini, mengkaji tentang kecenderungan keberpihakan media dan wartawan lokal dalam produksi berbeda, seperti sudut pengambilan engle berita, serta faktor-faktor lain yang mempengaruhi wartawan dalam menyajikan hasil liputan yang berbeda. Fokus studi pada media daring lokal dan nasional dengan memperhatikan beberapa hal Antara lain kedalaman informasi, upaya mengembalikan hak-hak kelompok Islam Syiah sebagai kelompok minuritas yang telah terusir dari kampung halamannya, serta analisa kecenderungan keberpihakan media lokal dalam menyajikan berita tentang konflik Syiah-Sunni tersebut yang hingga kini belum tuntas.
\end{abstract}

Kata Kunci: Jurnalis, Konflik, Sunni-Syi'ah Sampang

\begin{abstract}
Reporting on reporters' coverage of Sara's conflict between Shia Islamic groups and Sunni Islam groups that took place in Sampang Madura, East Java on August 26, 2012 caused one person to die, and six others were injured, and 47 Shiite homes were burnt by groups. attacker. At least 282 Shia residents in Karang Gayam Village, Omben Subdistrict, and Blu'uran Village, Karangpenang District, Sampang had to be evacuated due to the bloody conflict. This study, examines the tendency of the media and local journalists to take sides in different productions, such as the angle of taking engle news, and other factors that influence journalists in presenting different coverage of the coverage. The focus of the study is on local and national online media by taking into account several things, including the depth of information, efforts to restore the rights of Shiite Islamic groups as a group of minors who have been expelled from their homes, and analysis of local media bias in presenting news about the Shiite-Sunni conflict which until now has not been completed.
\end{abstract}

Keywords: Journalists, Conflict, Sunni-Shi'a Sampang 


\section{Pendahuluan}

Fokus studi tentang konflik bernuansa Sara atara kelompok Islam Syiah dan Sunni di Kabupaten Sampang, Pulau Madura, Provinsi Jawa Timur ini pada keterlibatan jurnalis dalam menyajikan informasi di media massa tentang konflik kedua kelompok berbeda aliran pemahaman dalam konflik tersebut. Penelitian ini merupakan pelangkap dari penelitian yang telah dilakukan sebelumnya oleh peneliti dan akademisi dari sejumlah Perguruan Tinggi

Setidaknya teridentifikasi sebanyak12 jurnal, 2 tesis dan 1 skripsi yang membahas konflik antara kelompok Islam Syiah dan Sunni di Sampang ini. Dua diantaranya diterbitkan pada tahun 2012, dua jurnal berikutnya pada 2013, sebanyak tiga jurnal diterbitkan pada 2013, lalu pada 2015 sebanyak empat jurnal, dua jurnal pada 2016, sisanya sebanyak dua jurnal tanpa disertai tahun penerbitan. Dua tesis hasil penelitian mahasiswa yang meneliti konflik tersebut masing-masing diterbitkan pada 2014 dan 2016². Sedangkan karya ilmiah jenis skripsi yang juga membahas tentang konflik Sunni-Syiah di Sampang, Madura ini adalah hasil penelitian mahasiswa Universitas Muhammadiyah (Unmuh) Malang pada tahun $2014^{2}$.

Karya ilmiah konflik Syiah dan Sunni yang terjadi di Kabupaten Sampang, Madura tersebut, kebanyakan meneliti tentang dampak konflik, upaya penyelesaikan konflik, telaah konflik dari kajian ekonomi dan politik aliran antara kelompok Islam Syiah dan Islam Sunni.

Dari berbagai penelitian lapangan tentang konflik Syiah-Sunni di Sampang, Madura tersebut, sebanyak empat laporan diantaranya merupakan hasil penelitian melalui kajian komunikasi berupa jurnal dan tesis. Masing-masing pada penilitian yang dilakukan Rachmah Ida dan Laurentius Dyson berjudul "Konflik Sunni-Syiah dan Dampaknya Terhadap Komunikasi Intra-religius pada Komunitas di SampangMadura"3 lalu penelitian yang dilakukan oleh Ferry Adhi Dharma berjudul "Kritik Terhadap Teori Spiral of Silence: Komunikasi Masyarakat Madura dalam Konflik Sunni-Syiah di Sampang"4, serta penelitian berjudul "Konflik Sampang: Sebuah Pendekatan Sosiologi-Komunikasi" yang dilakukan oleh Handrini Ardiyanti ${ }^{5}$.

\footnotetext{
1 Tesis yang membahas tentang konflik Sunni-Syiah di Sampang, Madura ini masing-masing berjudul "Penyelesaian Konflik Sunni-Syiah di Sampang, Madura" oleh Mundiroh Lailatul Munawwarah (Magister Humaniora UIN Sunan Kalijaga, Yogyakarta) pada tahun 2014 dan tesis berjudul "Eklusi dan Hambatan Komunikasi dalam Konflik Sunni-Syiah Sampang" oleh Ferry Adidharma, mahasiswa magister Program Studi Ilmu Komunikasi Universitas 11 Maret Surakarta, dan diterbitkan pada tahun 2016.

2 Skripsi tentang konflik Sunni-Syiah di Sampang ini oleh berjudul "Peran Pemerintah Daerah Penanganan Konflik Syiah Kabupaten Sampang (Studi di Desa Karang Gayam Kecamatan Omben)" oleh mahasiswa bernama Heri Yanto, jurusan Ilmu Pemerintahan pada Fakultas Ilmu Sosial Politik Universitas Muhammadiyah Malang. Skripsi ini diterbitkan pada tahun 2014.

3 Rachmah Ida dan Laurentius Dyson, Konflik Sunni-Syiah dan Dampaknya terhadap Komunikasi intra-religius pada Komunitas di Sampang-Madura, Jurnal Masyarakat, Kebudayaan dan Politik Vol. 28, No. 1, tahun 2015, hal. 33-49. Rachma Ida merupakan guru besar Komunikasi FISIP Uniar Surabaya dan Centre for Muslim State and Society, UWA, Australia, sedangkan Laurentius Dyson merupakan dosen Antropologi FISIP, Universitas Airlangga, Surabaya, Indonesia.

${ }^{4}$ Penelitian ini diterbitkan di jurnal INFORMASI Kajian Ilmu Komunikasi Volume 46. Nomor 1. Juni 2016.

${ }^{5}$ Lihat Handrini Ardiyanti, Konflik Sampang: Sebuah Pendekatan Sosiologi-Komunikasi, Politica Vol. 3, No. 2, November 2012.
} 
Sedangkan penelitian keempat berupa tesis tentang konflik antara kelompok Islam Syiah dan Sunni Sampang yang juga dalam perspektif kajian komunikasi yang ditulis oleh Ferry Adidharma, mahasiswa Universitas 11 Maret Surakarta6.

Konflik bernuansa Sara antara kelompok Islam Sunni dengan kelompok Islam Syiah di Kabupaten Sampang, Pulau Madura, Provinsi Jawa Timur terjadi pada 26 Agustus 2012. Satu orang tewas dan enam orang lainnya luka-luka serta sebanyak 47 rumah pengikut aliran Islam Syiah ludes dibakar massa penyerang. Sedikitnya 282 warga Syiah di Desa Karang Gayam, Kecamatan Omben, dan Desa Blu'uran, Kecamatan Karangpenang, Sampang harus dievakuasi akibat konflik berdarah tersebut.

Menurut Fathhul Khoir (Antara: 2012) dari Komite Orang Hilang dan Tindak Kekerasan (Kontras) Surabaya, tragedi kemanusiaan yang terjadi di Sampang, Madura pada 26 Agustus 2012 itu bermula ketika beberapa orangtua pengikut ajaran Syiah hendak mengantar sekitar 20 anak Syiah menuntut ilmu di Yayasan Pondok Pesantren Islam (YAPI), Bangil, Pasuruan, Jawa Timur. Pada sekitar pukul 10.00 WIB, sebelum keluar dari gerbang Desa Karang Gayam, rombongan pengantar dihadang oleh sekitar 30 orang bersepeda motor. Massa melengkapi dirinya dengan celurit, parang, serta benda tajam lainnya.

Anak-anak Syiah yang sudah naik angkutan umum disuruh turun, sedangkan yang mengendarai kendaraan dipaksa pulang ke rumah mereka masing-masing. Sebagaian warga Syiah yang berupaya melawan aksi itu justru membuat massa makin beringas sehingga bentrokan tidak terhindarkan. Satu persatu rumahrumah pengikut Islam Syiah di Desa Karang Gayam, Kecamatan Omben, dan Desa Bluuran, Kecamatan Karangpenang, Sampang dibakar. Aksi pembakaran itu mulai sekitar pukul 11.00 WIB siang, hingga sore sekitar 15.00 WIB masih berlangsung, dan diduga kuat memang telah terencana7.

Dugaan itu timbul, menyusul adanya temuan bahwa di setiap rumah yang dibakar terdapat tanda plastik berwarna merah di sekitar pekarangan rumah mereka, baik di Desa Karang Garam, Kecamatan Omben, maupun di Desa Bluuran, Kecamatan Karang Penang. Aparat kepolisian dan sebagian masyarakat menduga, plastik merah yang ada ditemukan setelah peristiwa penyerangan di sebagian pekarangan rumah pengikut Syiah itu, sebagai tanda, bahwa rumah tersebut yang seharusnya menjadi sasaran penyerangan.

Hasil investigasi Komisi untuk Orang Hilang dan Korban Tindak Kekerasan (Kontras) menyebutkan, penyebab utama konflik di Sampang, Madura, Jawa Timur itu, karena warga Sampang yang mayoritas menganut aliran Sunni, tidak menginginkan ada aliran lain yang berkembang di wilayah itu, sehingga Syiah dianggap aliran sesat yang harus dimusuhi dan diusir dari Sampang. Stigma tentang sesatnya ajaran Islam Syiah ini menyebar luas di kalangan masyarakat dan

\footnotetext{
${ }^{6}$ Penelitian oleh mahasiswa Magister Komunikasi itu berjudul "Eklusi dan Hambatan Komunikasi dalam Konflik Sunni-Syiah Sampang".

7 Fathhul Khoir (2012), Menyemai Benih Perdamaian dari Tragedi Sampang (2), Surabaya, jatim.antaranews.com diakses Kamis, 13 September 2012 10:24 WIB, pada laman: https://jatim.antaranews.com/berita/94999/menyemai-benih-perdamaian-dari-tragedi-sampang2
} 
digerakkan oleh tokoh-tokoh agama yang tidak menginginkan paham Syiah menyebar luas di Kabupaten Sampang8.

Penolakan akan adanya paham baru yang berbeda dengan paham mayoritas yang dianut masyarakat Sampang itu menjadi lebih kuat, setelah adanya Fatwa Majelis Ulama Indonesia (MUI) yang menyebutkan bahwa Syiah dan ajaran yang dibawa oleh pimpinan Syiah Sampang Tajul Muluk adalah sesat. Fatwa itu menjadi pemicu terjadinya kebencian antargolongan di internal umat Islam (Syiah dan Sunni) Sampang, hingga akhirnya menyebabkan terjadinya konflik terbuka yang puncaknya terjadi pada 26 Agustus 2012 tersebut.

Berbeda dengan hasil investigasi KontraS, Bupati Sampang Noer Tjahja kala itu menyatakan, bahwa pemicu konflik berdarah tersebut bukan karena perbedaan paham, antara kelompok Islam Sunni dengan Syiah, akan tetapi karena persoalan pribadi antara pimpinan Syiah Tajul Muluk dengan saudaranya Roisul Hukama yang akhirnya meluas menjadi konflik menjurus pertentangan Suku-Agama-Ras dan Antar-golongan (SARA) yang merepotkan banyak orang tersebut.

Kedua kakak-beradik ini (Tajul Muluk dan Roisul Hukama), dulunya samasama menganut ajaran Islam Syiah, kemudian terjadi persoalan keluarga, saat Rois hendak meminang santri Tajul Muluk yang bernama Halimah untuk menjadikan istrinya, akan tetapi ditentang oleh Tajul Muluk dengan cara menjodohkan dengan Abdul Aziz yang juga merupakan santri Tajul Muluk. "Jadi, sebenarnya tidak ada konflik Sunni-Syiah di Sampang ini," tutur Bupati Noer Tjahja, menegaskan.

Ketua Jamaah Syiah Sampang Iklil Almilal mengakui, masalah pribadi antara Tajul Muluk dengan Roisul Hukama memang menjadi salah satu pemicu renggangnya hubungan kekeluargaan di antara mereka. Akan tetapi, menurut Iklil, hubungan asmara antara Rois dengan gadis Halimah, bukan satu-satunya penyebab, terjadinya aksi penyerangan terhadap kelompok Islam Syiah di Sampang, Madura, namun persoalan yang pokok adanya gerakan permusuhan dari sebagian tokoh-tokoh Sunni hingga akhirnya menyebabkan adanya aksi penyerangan terhadap kelompok Syiah, karena aliran Islam yang ada dipimpin oleh Tajul Muluk itu dianggap sebagai ajaran Islam sesat.

Kalau hanya masalah keluarga, apalagi perempuan, tidak mungkin massa dalam jumlah banyak akan bergerak melakukan penyerangan terhadap warga Syiah. "Kami mendengar dengan jelas yang mereka sampaikan, bahwa Syiah adalah ajaran yang sesat, dan harus disingkirkan dari Sampang, Madura ini," kata Iklil Almilal seperti dilansir Antara, Kamis, 13 September $2012^{10}$.

Geneologi masuknya ajaran Syiah ke Sampang, Madura awalnya dipelopori oleh Kiai Makmun, seorang ulama sekaligus ayah Tajul Muluk dan Iklil Almilal yang awalnya beraliran Sunni di Dusun Nangkernang, Desa Karang Gayam, Sampang. Ini terjadi setelah Kiai Makmun mendapat kabar dari sahabatnya di Iran mengenai revolusi Iran. Keberhasilan yang diraih kaum ulama Iran yang dipimpin Ayatullah

\footnotetext{
8 Tokoh ulama Madura yang dikenal gigih menolak penyebaran paham Syiah di Sampang, Madura adalah KH Ali Karrar Shinhaji, asal Proppo, Pamekasan, dan tokoh ini juga banyak memiliki santri alumni di Kecamatan Omben dan Kacamatan Karang Penang, Sampang.

9 Noer Tjahja (2012), Menyemai Benih Perdamaian dari Tragedi Sampang (1), Surabaya, jatim.antaranews.com, diakses Kamis, 13 September 2012 10:15 WIB pada laman: https://jatim.antaranews.com/berita/94998/menyemai-benih-perdamaian-dari-tragedi-sampang1. 10 Ibid.
} 
Ali Khomeini kala itu menumbangkan rezim monarki pimpinan Syah Iran Reza Pahlevi menjadi sumber inspirasi sekaligus tokoh panutan bagi Kiai Makmun.

Berawal dari ketertarikannya pada kesuksesan revolusi Iran itu, Kiai Makmun mulai mempelajari kitab-kitab aliran Syiah. Pada tahun 1983, kiai Makmun mengirimkan empat anaknya yakni Iklil Almilal, Tajul Muluk, Roisul Hukama dan putrinya, Ummi Hani untuk belajar tentang Syiah ke Pondok Pesantren Yayasan Pesantren Islam (YAPI) di Bangil, Pasuruan, Jawa Timur. Selepas lulus SMP YAPI, Tajul Muluk melanjutkan belajar ke Pondok Pesantren Sayyid Muhammad Al-Maliki di Arab Saudi. Tahun 1999 Tajul Muluk pulang dari Arab dan kembali menetap di Karang Gayam, Sampang. Tahun 2004 sejumlah warga desa yang juga murid Kiai Makmun mewakafkan sebidang tanah untuk mengembangkan pesantren beraliran Syiah. Pesantren kecil ini diberi nama Misbahul Huda dan sejak saat ini penyebaran ajaran Syiah mulai dilakukan ${ }^{11}$.

Menurut Hendriyani (2012), jika melihat latar belakang terjadinya konflik Sampang diketahui bahwa konflik tersebut justru berawal dari level pimpinan yaitu merupakan konflik perebutan basis otoritas kepemimpinan agama. Para kiai Sunni/NU adalah kelompok superordinat yang selama ini menikmati posisinya sebagai pemimpin agama karena nilai-nilai ke-sunni-an/ke-NU-an sebagai nilainilai keagamaan bersama yang absah. Berbagai pendapat yang disebarkan komunitas Sunni dan kelompok lain dengan mengatakan bahwa Syiah merupakan kelompok sesat adalah upaya mendelitimasi Syiah dan pada akhirnya menimbulkan stereotip yang begitu kuat dalam masyarakat. Kelompok Tajul Muluk menjadi kelompok yang tidak disukai sehingga berujung pada menajamnya konfrontasi yang berakhir pada konflik terbuka dari tahun ke tahun diantaranya pada Desember 2010. Kala itu, beberapa warga melaporkan aktivitas ustad Tajul Muluk dan jamaah Syiahnya ke Majelis Ulama Indonesia (MUI) Sampang12.

Konflik yang terjadi di Sampang, Madura ini, menjadi perhatian banyak kalangan. Berita tentang tragedi kemanusiaan dalam bentuk penyerahan oleh kelompok mayoritas terhadap kelompok minoritas tersebut menjadi perhatian semua pihak, bahkan kasus ini juga menjadi perhatian media asing. Mereka menilai konflik bernuansa Sara ini dengan sudut pandang berbeda, sesuai dengan sudut pandang yang mereka gunakan, termasuk media dalam memberita konflik tersebut.

Porsi pemberitaan media atas konflik ini sangat dominan dan selalu menjadi teras berita berbagai media cetak di Indonesia, baik media lokal, regional maupun media massa dalam nasional.

Sebagaimana sudut pandang masyarakat, tokoh agama, pemerintah, dan pegiat Lembaga Sosial Masyarakat (LSM) yang berbeda, sudut pandang media dalam penyajian berita atau "enggle berita" juga cenderung berbeda dalam memberitakan konflik Syiah-Sunni di Desa Karang Garam, Kecamatan Omben dan

${ }^{11}$ Hendriani Ardiyanti (2012), Konflik Sampang: Sebuah Pendekatan Sosiologi-Komunikasi, Politica Vol. 3, No. 2, November 2012, hlm. 231.

${ }^{12}$ Konflik yang terjadi pada Desember 2010 merupakan konflik awal, ketika sebagian warga Sunni yang tidak suka dengan adanya paham berbeda mulai melakukan serangkaian upaya pengopinian kepada publik bahwa Syiah merupakan ajaran Islam yang sesat, dan konflik ini kemudian berlanjut ke konflik berikutnya, yakni pada 2 April 2011 dan hingga konflik terakhir yang menyebabkan warga Syiah harus menungungsi dan terusir dari kampung halamannya pada 26 Agustus 2012. Ibid, hlm 232. 
Desa Blu'uran, Kecamatan Karang Penang, Kabupaten Sampang yang terjadi 26 Agustus 2012 tersebut.

\section{Metode Penelitian}

Metode kajian tentang konflik Syiah -Sunni di Sampang, Madura, Jawa Timur ini dengan mengajukan rumusan masalah, bagaimana Jurnalis memframing berita konflik antara kelompok Islam Syiah dan Sunni yang terjadi di Kabupaten Sampang, pada 26 Agustus 2016? Mengapa media cenderung memiliki sudut pandang berbeda dalam menyajikan berita dalam kasus konflik bernuansa Sara antara kelompok Islam Sunni dan Kelompok Islam Syiah tersebut, terutama media lokal, Madura? Faktor-faktor apa saja yang berpotensi mempengaruhi media dan wartawan dalam menyajikan berita untuk khalayak? Pengumpulan data dilakukan dengan menelaah hasil penelitian di beberapa jurnal tentang konflik Syiah dan Sunni di Kabupaten Sampang, serta pemberitaan media tentang konflik tersebut, membandingkan antara media lokal, dengan media nasional. Selanjutnya, dari hasil pengumpulan data itu, penulis melakukan telaah dengan menggunakan teori ekonomi politik media ${ }^{13}$, sehingga bisa diperoleh pemahaman yang konprehensif tentang persoalan tersebut. Selain itu, penulis juga meneliti tentang tema-tema pemberitaan media dalam menyajikan berita konflik Syiah - Sunni di Sampang, Madura, mulai saat kejadian, hingga saat ini, terutama dalam upaya memberikan stigmatisasi kepada kedua belah pihak, serta upaya-upaya yang dilakukan pemerintah untuk mendamaikan keduanya, dan mengembalikan hak-hak korban konflik. Media yang menjadi fokus studi ini adalah tempo.co, kompas.com untuk media nasional, dan maduracorner.com untuk media lokal, serta beritajatim.com untuk media regional.

\section{Pembahasan}

Konflik bernuansa Sara antara kelompok Islam Syiah dan kelompok Islam Sunni di Kabupaten Sampang, Madura menyitasa trauma yang mendalam kepada para korban, terutama kelompok Syiah. Sebab, selain harus hidup secara terisolir, karena berpaham berbeda dengan paham mayoritas umat Islam disana, konflik itu, juga menyisakan trama yang mendalam bagi anak-anak. Satu orang tewas dan enam orang lainnya luka-luka serta sebanyak 47 rumah pengikut aliran Islam Syiah ludes dibakar massa penyerang. Sedikitnya 282 warga Syiah di Desa Karang Gayam, Kecamatan Omben dan Desa Blu'uran, Kecamatan Karang Penang tersebut. Konflik ini juga telah mengakibatkan warga Syiah diungsikan ke Rumah Susun di komplek pasar Puspa Agro, Desa Jemundo Sidoarjo.

Berdasarkan hasil kajian dari sejumlah sumber menunjukkan, bahwa latar belakang adanya konflik ini sangat komplek, meliputi ideologi, keluarga, ekonomi serta Politik. Secara ideologis, antara Sunni dan Syiah memiliki riwayat konflik yang cukup panjang yang diakibatkan oleh perbedaan cara pandang mengenai status Ali bin Abi Thalib. Oleh karena itu, kemunculan Keputusan fatwa Majelis Ulama Indonesia (MUI) Propinsi Jawa Timur No. Kep-01/SKF-MUI/JTM/I/2012 yang menyatakan Syiah sebagai aliran sesat juga menjadi variabel pemicu

13 Teori tentang ekonomi politik yang menjadi pisau analisa dalam kajian ini adalah teori Pamela J. Shoemaker dan Stephen D. Reese (1996), dalam Mediating The Message: Theories of Influences on Mass Media Content. 
terjadinya konflik horizontal di Karang Gayam Omben Sampang. Selain itu, juga disebabkan oleh adanya pernyataan dari Pengurus Wilayah NU dan Ulama Badan Silaturrahmi Ulama Pesantren Madura yang menyatakan bahwa Syiah sebagai aliran sesat sehingga penganut harus dibaiat kembali ke Sunni. (Mundiroh. 2014 dalam Hazim, 2015: 10).

Hasil penelitian Hazim menyebutkan ada delapan dampak sosial yang terjadi akibat konflik bernuansa Sara antara kelompok Islam Syiah dan kelompok Islam Sunni di Sampang, Madura, Jawa Timur itu14. Pertama). Kehilangan tempat tinggal untuk sementara waktu, bahkan tidak menutup kemungkinan bisa terjadi untuk seterusnya jika penduduk di wilayah konflik ini tidak tercipta kesepakatan yang memungkinkan kedua belah pihak bisa hidup berdampingan secara aman dan damai kembali. Berdasarkan informasi dari Iklil (Koordinator Pengungsi Syiah) sebanyak sekitar 80 rumah warga Syiah yang terbakar dari dua Desa juga belum ada pihak yang membantu merehab kembali. Sementara itu, dari Pemerintah belum memberikan kepastian alternatif solusi, apakah akan disiapkan tempat tinggal baru, atau dipulangkan, atau alternatif pemecahan yang lain. Kedua, kehilangan sumber mata pencaharian. Sebelumnya, mayoritas mereka adalah petani yang sangat tergantung dengan lahan yang dimiliki di Desanya sebagai sumber ekonomi. Ketika mereka pindah dari desanya dan harus tinggal di pengungsian, mereka sudah tidak memungkinkan lagi menggarap lahannya di desa asal sementara ternaknya terpaksa harus dijual untuk menyelamatkan asetnya. Bahkan pada saat kejadian, sejumlah warga Syiah masih memiliki tanaman tembakau siap panen, tapi tidak sempat dipanen karena kondisi tidak memungkinkan. Untuk menambah penghasilan di pengungsian, sebagian aktivitas mata pencahariannya hanya mengandalkan sebagai buruh di pasar Puspa Agrowisata dengan penghasilan yang tidak menentu. Di antaranya ada yang bekerja sebagai pengupas kelapa dengan upah yang minim, itupun tidak setiap hari.

Ketiga, Tercipta ketergantungan dengan pihak lain. Untuk memenuhi kebutuhan hidupnya di pengungsian mereka mendapat disubsidi dari Pemerintah Propinsi Jawa Timur, berupa uang sebesarRp709.000 perjiwa. Hanya saja pengungsi tidak tahu hingga kapan subsidi ini akan diberikan. Pada saat yang sama, pengungsi dengan kondisi yang mengalami banyak keterbatasan juga secara umum tidak memiliki rencana alternatif untuk mendapatkan income seandainya subsidi ini dihentikan. Keempat, Terganggunya pendidikan anak-anak dalam pengungsian. Saat ini, terdapat 1 anak SMA, 2 anak SMP, dan 50 anak duduk di bangku SD. Untuk anak usia SMP dan SMA difasilitasi sekolah di desa sekitar pengungsian. Sementara yang SD difasilitasi sekolah di dalam komplek rumah Susun diperuntukkan khusus bagi anak pengungsi. Kondisinya pun jauh dari standart kualitas pendidikan. Karena keterbatasan dalam banyak aspek, Anakanak SD dikelompokkan hanya dalam 2 ruang kelas. Satu ruang untuk anak kelas 1-3, dan satu ruang untuk anak kelas 4-6 SD. Tentu ini bukan hal yang mudah bagi guru untuk mendidik para siswa dalam satu kelas dengan tingkatan kemampuan dan usia yang beragam. Apalagi fasilitas yang dimiliki juga sangat terbatas. Jika kondisi ini terus berlangsung, maka akan sangat berpengaruh pada perkembangan

14 Hasyim (2015), Dampak Sosial dan Psikolososial bagi Pengungsi Pasca-Konflik antara Sunni-Syiah di Sampang Madura, Psikologi/ Vol: 3 No. 1, hlm.10 
psikologis anak, dan selanjutnya akan sangat berdampak pada rendahnya Sumber Daya Manusia bagi generasi mendatang yang sekarang mengungsi ini.

Kelima. Bagi anak-anak, mengalami gangguan psikologis karena mereka berada dalam pusaran konflik secara berulang-ulang. Dampaknya anak-anak akan terbiasa dalam kondisi kekerasan, sehingga bukan tidak mungkin mereka kelak akan tumbuh menjadi anak yang bermental kasar dan frontal yang diakibatkan oleh akumulasi pengalaman kekerasan yang dialami. Keenam, terpasung kebebasan dasar mereka. Dalam pengungsian, mereka menjadi kelompok yang teralienasi dari masyarakat. Padahal Manusia merupakan makhluk sosial yang membutuhkan interaksi satu sama lain dalam rangka pemenuhan kebutuhan hidupnya, baik yang bersifat fisik maupun psikologis. Keberadaannya di pengungsian, membuat mereka mengalami keterbatasan dalam hal berinteraksi. Mereka tidak memiliki kebebasan untuk berinteraksi dengan komunitas di luar pengungsi. Lebih-lebih pada anak yang memerlukan stimulan interaksi dari masyarakat lebih luas lebih dari sekedar komunitasnya di pengungsian untuk mendukung pengembangan dirinya, secara mental maupun sosial.

Ketujuh,Terbatasnya akses layanan sosial kesehatan. Sejak keberadaan mereka di pengungsian Puspa Agro, sudah terdapat sebanyak 5 Ibu yang melahirkan. Tragisnya, mereka melahirkan di tempat tinggalnya di pengungsian tanpa di dampingi oleh tenaga medis. Padahal melahirkan merupakan saat yang sangat beresiko dan sejumlah kemungkinan buruk bisa saja terjadi. Untungnya mereka bisa menjalani persalinan dengan selamat. Kedelapan, dampak lain yang harus menjadi perhatian dalam jangka panjang adalah terjadi pemiskinan yang akan dialami oleh para pengungsi, karena mereka tidak memiliki kepastian penghasilan maupun kepemilikan aset. Aset lama yang berada di tempat tinggal asal tidak terkelola dengan baik, sementara di pengungsian tidak cukup memiliki kesempatan untuk memperoleh aset kehidupan yang baru. Sedangkan Subsidi dari Pemerintah hanya cukup untuk pemenuhan kebutuhan konsumtif sehari-hari.

Kedepalan dampak sosial yang dialami korban konflik bernuasa Sara dalam kelompok Islam Syiah ini, merupakan akibat dari peristiwa yang terjadi pada 26 Agustus 2012 tersebut yang dipicu oleh politik kuasa kelompok mayoritas, yakni Sunni yang tidak menginginkan paham Syiah berkembang di Sampang, Madura. Fatwa MUI bahwa Syiah merupakan aliran sesat menjadi dasar bagi masyarakat Sampang untuk mengusir kelompok ini, termasuk mengusir mereka dari tanah kelahirannya.

\section{Gerakan Politik Syiah}

Secara umum, masyarakat Syiah di desa Karang Gayam tidak jauh berbeda dengan masyarakat Sunni pada umumnya, baik dari segi perekonomianmaupun dari segi keilmuannya. Namun yang membedakan di antaranya adalah sebagian ajaran-ajaran yang mereka anut, dan kebanyakan masyarakat Syiah merupakan pengikut atau jama"ah dari kyai Makmun (ayah Tajul), yang sangat mengabdikan diri kepada gurunya itu, sehingga hal ini semakin memudahkan Tajul dalam merekrut masyarakat untuk menjadi pengikutnya ${ }^{15}$.

\footnotetext{
15 Hadori, Gerakan Politik Syiah-Sunni di Desa Karang Gayam dan Blu'uran Sampang Madura, Jurnal Review Politik Volume 05, Nomor 02, Desember, hlm. 235.
} 
Di Madura, beberapa tahun belakangan, gerakan politik Syiah yang dibawa Tajul merupakan paham fenomenal, setidaknya setelah terjadinya kekerasan terhadap penganut ajaran Syiah di Sampang Madura. Konflik kepemimpinan yang oleh media dianggap sebagai konflik kepemimpinan/kekuasaan antardua paham yang berbeda, yaitu Sunni dan Syiah menggambarkan tentang hubungan disharmoni antara kedua aliran tersebut. Sunni yang dalam konteks Madura identik dengan warga NU, merupakan penganut terbanyak di Sampang, dan bahkan di Madura. Mayoritas masyarakat Madura merupakan penganut NU, sehingga aliran ini menjadi aliran terbesar yang diyakini oleh masyarakat Madura, khususnya masyarakat Sampang.

Awal mula masuknya Syiah ke Madura dipelopori oleh Kiai Makmun, seorang ulama sekaligus ayah Tajul Muluk dan Iklil al-Milal yang awalnya beraliran Sunni di Nangkernang, Desa Karang Gayam, Sampang. Ini terjadi setelah Kiai Makmun mendapat kabar dari sahabatnya di Iran mengenai revolusi Iran. Keberhasilan yang diraih kaum ulama Iran yang dipimpin Ayatullah Ali Khomeini dan berhasil menumbangkan Syah Iran Reza Pahlevi (sebuah rezim yang dianggap monarki) menjadi sumber inspirasi sekaligus tokoh panutan bagi Kia Makmun dalam membela ketidakadilan yang terjadi di desanya ${ }^{16}$. Keberhasilan kaum ulama Iran yang dipimpin Ayatullah Ali Khomeini menumbangkan Syah Iran Reza Pahlevi (sebuah rezim yang dianggap monarki yang didukung oleh USA) menjadi sumber inspirasi bagi Kyai Makmun. Karena mayoritas ulama dan kaum muslim di wilayah Madura adalah pengikut Islam NU yang fanatik, kemudian mulailah kyai Makmun mempelajari Syiah secara diam-diam dengan membaca buku-buku yang dikirim sahabatnya dari Iran.

Konflik yang terjadi di Sampang, awalnya pada tanggal 4 April 2011. Kala itu, Tajul akan mengadakan acara Maulid Nabi. Acara ini sejak awal mendapatkan resistensi yang sangat keras dari masyarakat sekitar. Sejak sebelum hari $\mathrm{H}$, masyarakat Sunni melakukan berbagai upaya untuk menggagalkannya. Massa memblokade tempat acara. Dengan bersenjatakan clurit, parang, golok, pentungan, dan senjata tajam lainnya, mereka menghadang jama"ah yang hendak menghadiri acara Maulid Nabi. Jika jamaah Syiah tetap bersikukuh melangsungkan acara Maulid Nabi, sangat mungkin ada carok masal. Ancaman ini tidak main-main. Sejak awal, masyarakat menunjukkan kebenciannya terhadap keberadaan Syiah di wilayahnya. Akhirnya, acara Maulid itu gagal dilaksanakan.

Puncaknya adalah peristiwa terjadi pada tanggal 26 Agustus 2012 antara kelompok Tajul Muluk al Ali Murtadha (penganut aliran Syiah) dengan kelompok M Roisul Hukam (penganut aliran Sunni) yang mengakibatkan satu orang meninggal dunia, dan beberapa orang lainnya luka-luka.

Perseteruan berawal dari sebuah keluarga terpengaruh, yakni antara Kiai Tajul Muluk (Syiah) dan Kiai Rois (Sunni), ketika pada suatu ketika, kiai Rois berkeinginan untuk menikahi salah satu santri putri Kiai Tajul Muluk. Namun, hasrat Kiai Rois tidak dipenuhi oleh Kiai Tajul Muluk. Pasalnya, kiai Rois tukang kawin dan tabiat negatif itu kurang mendapat tempat di hatinya. Sehingga ia melarang Kiai Rois mempersunting salah satu santri putrinya. Lantaran merasa ditentang, emosi jiwa muda Kiai Rois meledak-ledak dan mengajak pihak-pihak

16 Ibid, hlm 237 
lain yang memang memiliki sentimen negatif kepada Kiai Tajul Muluk untuk melampiaskan amarahnya. Amarah Kiai Rois tersalurkan dengan melakukan pembakaran pesantren dan rumah ibu serta adiknya. Kebetulan Kiai Tajul Muluk ini dakwahnya mulai naik daun dan mungkin ada yang merasa tersaingi. Pihakpihak yang tersaingi inilah yang ditunggangi atau dimanfaatkan oleh Kiai Rois untuk membalas sakit hatinya karena gagal melancarkan hasrat menikahi salah satu santri Kiai Tajul.

Metamorfosan ajaran Syiah Sebagai Gerakan Politik di Desa Karang Gayam berawal ketika Tajul menyebarkan ajaran Syiah dengan mudah dan dibantu saudara-saudaranya. Program-program sosial yang dijalankan oleh Tajul juga cukup efektif, karena ia banyak membantu orang yang kekurangan. Syi"ah sudah mendarah daging di hati masyarakat dan tidak bisa di otak atik lagi karena masyarakat telah mantap dengan apa yang disampaikan Tajul bahwa Syi"ah telah diajarkan oleh sesepuhnya dan para habaib. Apalagi Tajul pernah tinggal di Makkah, sehingga makin memantapkan keyakinan masyarakat.

Gerakan Tajul dimulai memindahkan acara itu di masjid dengan gotong royong dan swadaya, khususnya pada acara peringatan Maulid Nabi. Ini mengusik kepentingan kiai, karena warga merasa Tajul meringankan mereka. Gerakan Syiah merupakan hal baru bagi masyarakat Sampang khususnya di Desa Karang Gayam itu sendiri. maka pensosialisasian Gerakan Syiah ini sangatlah penting adanya. Pensosialisasian Gerakan Syiah ini dikampanyekan atau dikomunikasikan secara langsung kepada masyarakat karena secara emosional komunikasi ini lebih bersifat interaktif, dengan menggunakan acara pengajian atau perkumpulan sebagai strategi atau konsep kepemimpinannya. Pada akhirnya, hanya sekitar tiga tahun, ratusan warga di desa Karang Gayam dan Blu'uran (desa tetangga) telah menjadi pengikut Syiah dan murid Tajul yang setia.

\section{Pemberitaan Media}

Konflik bernuansa Sara yang terjadi di Sampang, Madura, Jawa Timur pada 26 Agustus 2012 tidak luput dari pemberitaan media, apalagi konflik itu merupakan bentuk "penindasan" dari kelompok masyarakat yang mayoritas yakni Sunni, terhadap kelompok kecil yang minoritas, yakni kelompok Islam Syiah. Kasus yang menyebabkan satu orang tewas dan enam orang lainnya luka-luka, serta sebanyak 47 unit rumah warga Syiah dibakar kelompok penyerang itu, menjadi headline di berbagai media di Indonesia, baik media lokal, regional, nasional, bahkan media luar negeri, seperti BBC, VOA dan CNN.

Pada awal kejadian, yakni selama kurun waktu Agustus 2012 hingga Desember 2012, pemberitaan di sejumlah media tentang konflik Syiah-Sunni di Sampang itu, masih seputar tentang peristiwa, seperti kronologis kejadian, penangkapan pelaku pembakaran rumah warga Syiah, serta pengungsian warga Syiah di Gedung Olahraga Wijaya Kusuma Sampang.

Kronologi tentang penyerangan warga Syiah oleh kelompok Islam Sunni tersebut antara lain diberitakan oleh Tempo.co, Antaranews.Com, Detik.com, Kompas.com, serta sejumlah media nasional lainnya, termasuk beberapa surat kabar lokal di Madura, seperti Koran Harian Radar Madura, Kabar Madura dan MediaMadura.Com. 
Selain itu, jenis berita lainnya seputar penanganan pengungsi, seperti ketersediaan MCK, tempat tidur, dapur umum, serta berbagai jenis kegiatan kunjungan dari pemerintah, baik pemerintah provinsi, pusat, maupun lembaga legislatif. Berbagai jenis bantuan kemanusiaan terus mengalir, baik dari dalam negeri maupun luar negeri, serta penanganan dan upaya penyelesaian konflik, termasuk upaya Pemkab Sampang dalam menyelesaikan kasus tersebut. Media nasional seperti tempo.co dan kompas.com lebih banyak mengangkat topik-topik pemberitaan mengenai konflik Sunni-Syiah yang terjadi pada 26 Agustus $2012 \mathrm{itu}$, tentang pentingnya mengakui keberadaan kelompok minuritas dan mengembalikan hak-hak warga Syiah, serta lemahnya peran negara dalam upaya menciptakan keamanan, sehingga kelompok kecil di Sampang itu harus terusir dan tertindas.

Salah satunya seperti yang diberitakan tempo.co pada 28 Agustus 2012 berjudul "Solusi Konflik Sampang Versi Pemerintah". Berita ini mengangkat keterangan pers Menteri Agama Suryadharma Ali yang mengatakan bahwa pemerintah tengah berupaya mengembalikan rasa aman warga Sampang seusai terjadinya tindak kekerasan terhadap komunitas Syiah yang terjadi pada 26 Agustus 2012, dan mereka terpaksa harus mengungsi. Diantaranya terkait aspek kemanusiaan, mulai dari konsumsi dan pakaian pengungsi, serta jaminan dari pemerintah bahwa anak-anak korban konflik agar tetap bisa mengenyam pendidikan ${ }^{17}$. Dalam berita itu juga dijelaskan, bahwa akar konflik antara kedua kelompok berbeda aliran tersebut karena persoalan keluarga. Menag juga mengemukakan, bahwa dialog merupakan salah satu upaya untuk menciptakan perdamaian dan mewujudkan kesepahaman antara kedua belah pihak yang bertikai tersebut ${ }^{18}$.

Tema berita tentang upaya penyelesaian konflik Syiah-Sunni di Sampang yang diberitakan tempo.co ini merupakan sebagian dari sebanyak 407 berita yang dilansir media tersebut selama kurun waktu 2012 hingga 2018 kali ini ${ }^{19}$. Dari jumlah itu, sebanyak 40 berita diantara mengangkat tema tentang upaya perdamaian yang dilakukan semua elemen baik masyarakat, pemerintah, maupun kedua belah pihak yang berkonflik.

Media nasional lainnya adalah kompas.com. Pada awal konflik terjadi, media ini juga lebih banyak memberitakan tentang upaya-upaya perdamaian yang dilakukan para pihak untuk meredam konflik Syiah-Sunni yang menewaskan satu orang dan beberapa orang lainnya tersebut luka-luka. Kompas menyajikan berita upaya damai dalam konflik Syiah-Sunni di Sampang Madura itu, dari berbagai sisi, baik dari sisi keamanan, tanggungjawab kemanusian, maupun dari sisi penegakan supremasi hukum bagi para pihak yang telah menyebabkan "tragedi kemanusiaan" itu terjadi.

\footnotetext{
17 Suryadharma Ali (2012), Solusi Konflik Sampang Versi Pemerintah, tempo.co, diakses 28 Agustus 2012 pada laman: https://nasional.tempo.co/read/426083/solusi-konflik-sampang-versi-pemerintah ${ }^{18}$ Suryadharma Ali (2012), Menag: Dialog Solusi Cepat Ricuh Sampang, Madura, tempo.co, diakses 29 Agustus 2012 pada laman: https://nasional.tempo.co/read/426136/menag-dialog-solusi-cepatricuh-sampang-madura

19 Data jumlah berita tentang konflik Syiah-Sunni di Sampang, Madura di media tempo.co ini didasarkan pada mesin pencari yang ada di media tersebut dengan menggunakan kata "Syiah-Sunni Sampang"
} 
Diantara 330 berita tentang konflik Syiah - Sunni yang dilansir situs media nasional kompas.com selama kurun waktu 2012 hingga $2018 \mathrm{itu}$, diantaranya berita berjudul "Penyelesaian Konflik Sampang Kuncinya Ada di Kyai Madura". Berita yang dilaporkan oleh kontributor Yatimul Ainun pada 1 September 2012 itu, memuat komentar almarhum mantan Ketua Pengurus Besar Nahdlatul Ulama (PBNU) Hasyim Muzadi yang menyebutkan bahwa kasus Sampang itu terjadi karena selisih paham, dan oleh karenanya, yang bisa menyelesaikan konflik tersebut adalah para ulama Madura itu sendiri ${ }^{20}$. Media ini diawal kejadian juga memberitakan bahwa konflik yang terjadi di Sampang itu, bukan Syiah dengan Sunni dengan memilih narasumber Menteri Dalam Negeri Gamawan Fauzi kala itu $^{21}$, bahkan sempat memberitakan bahwa sumber konflik adalah Syiah, dengan narasumber Ketua Majelis Ulama Indonesia perwakilan Provinsi Jawa Timur (MUI Jatim) KH Abdusshomad Buchori22.

Media lokal Madura, sebagian menjastifikasi dan menggambarkan bahwa kelompok aliran Syiah di Sampang, Madura itu memang kelompok yang sesat. Sehingga media ini cenderung lebih mengekplorasi berita yang "memojokkan" Syiah, seperti berita berjudul "23 orang Penganut Syiah Sampang, Kembali Ke Sunni" sebagaimana dilansir situs maduracorner.com pada 3 November $2012^{23}$. Dalam berita yang dilansir media daring yang berkantor di Kabupaten Bangkalan itu dijelaskan, sebanyak 8 Kepala Keluarga (KK) atau 23 orang penganut aliran Syiah di desa Blu'uran, Kecamatan Karang Penang, Kabupaten Sampang, yang masih tinggal di lokasi konflik kembali ke ajaran yang mereka anut sebelumnya yakni Ahlussunnah Wal Jemaah (Sunni). Upacara kembalinya penganut ajaran Syiah ke ajaran Sunni tersebut dipusatkan di Pondok Pesantren (Ponpes) Darul Ulum, desa Gersempal, Kecamatan Omben, yang di pimpin langsung oleh KH. Lutfi Lah Ridwan serta dihadiri perwakilan dari Polres Sampang, Kemenag, Para ulama serta sejumlah tokoh masyarakat setempat. "Dari 8 kepala keluarga itu sebanyak 23 orang yang sudah kembali ke ajaran Sunni dan sebelumnya di tempat yang sama pada tangga 24 Oktober lalu sebanyak 15 KK sudah kembali ke ajaran Sunni," ujar Kepala Bakesbangpol Sampang, Rudi Setiadi melalui Kabid Kewaspadaan Soekrisno hadi, saat dikonfirmasi, Jumat (02/11/2012).

Berita di media ini juga menjelaskan, bahwa dalam upacara kembalinya sejumlah penganut aliran Syiah di desa Blu'uran, Kecamatan Karang Penang ke ajaran Ahlussunah Wal Jamaah (Sunni) tersebut diawali dengan pembacaan dua

${ }^{20}$ Hasyim Muzadi (2012), Penyelesaian Konflik Sampang Kuncinya Ada di Kyai Madura, kompas.com diakses pada 11 September 2012 pada laman: https://nasional.kompas.com/read/2012/09/01/14081997/penyelesaian.konflik.sampang.kuncinya. ada.di.kyai.madura.

${ }^{21}$ Gamawan Fauzi, Mendagri: Konflik di Sampang Bukan Sunni-Syiah, kompas.com, 28 Agustus 2012 pada laman: https://nasional.kompas.com/read/2012/08/28/14502998/Mendagri.Konflik.di.Sampang.Bukan. Sunni.Syiah.

${ }^{22}$ KH Abdusshomad Buchori, MUI Jatim: Kalau Syiah Masih Ada, Tetap Ada Konflik, kompas.com, 3 September 2012 pada laman: https://nasional.kompas.com/read/2012/09/03/15355642/MUI.Jatim.Kalau.Syiah.Masih.Ada.Tet ap.Ada.Konflik.

${ }^{23}$ KH. Lutfi Lah Ridwan, 23 orang Penganut Syiah Sampang, Kembali Ke Sunni, maduracorner.com, diakses 3 November 2012 pada laman: http://www.maduracorner.com/23-orang-penganut-syiahsampang-kembali-ke-sunni/ 
kalimat Syahadat yang dipimpim oleh KH. Lutfi Lah Ridwan dilanjutkan dengan pembacaan ikrar bahwa mereka tidak akan kembali lagi ke aliran Syiah ${ }^{24}$. Berita serupa tentang 23 penganut Syiah yang kembali keajaran Sunni tersebut juga dilansir beritajatim.com, yakni media daring regional Jawa Timur yang berkantor di Surabaya. Bahkan media ini memberitakan, adanya warga Syiah yang kembali ke ajaran Sunni tersebut bukan yang pertama kali. Sebab, sebelumnya, pada 24 Oktober 2012 di tempat yang sama sebanyak 15 KK penganut syiah yang tinggal di Desa Karang Gayam kecamatan Omben, juga sudah kembali ke aliran ahli sunnah wal jamaah ${ }^{25}$.

\section{Akar Ekopol Media di Konflik Sampang}

Ekonomi politik media merupakan istilah yang digunakan secara umum untuk memadukan kerangka teoriti komunikasi dengan kerangka teoritik politik dan ekonomi. Sebagai entitas yang dikonstruksi oleh media, apa yang disebut sebagai komunikasi sering merepresentasikan kepentingan ekonomi sekaligus politik tertentu. Pakar komunikasi dan ilmuan Vincent Mosco dalam bukunya "The Political Economy of Communication" menyebutkan bahwa pendekatan ekonomi politik ini berdasar pada pengertian ekonomi politik sebagai studi mengenai relasi sosial, yang dikonstruksi oleh media untuk merepresentasikan kepentingan ekonomi sekaligus politik tertentu, menyangkut relasi kekuasaan ini adalah ditekankan pada konsep sejauh mana media mengambil posisi dalam kepentingan praktis dan ideologi, dalam seting kepemilikan (ekonomi) dan setting kekuasaan (politik).

Disisi lain, masyarakat memandang berita sebagai sebuah fakta di lapangan yang kemudian disajikan apa adanya oleh media. Hal ini menyebabkan masayarakat merasa terkejut saat menyaksikan apa yang ditayangkan di media ternyata tidak sama dengan apa yang mereka saksikan. Dengan kata lain, apa yang ditampilkan media sudah melalui berbagai proses sehingga hasilnya tidak utuh lagi seperti fakta. Memang, tidak semua fakta bisa ditampilkan utuh dalam berita, tapi paling tidak campur tangan atau rekayasanya tidak terlalu menyimpang dari kondisi yang sesungguhnya. Dengan demikian, masyarakat harus menyadari berbagai pengaruh yang dihadapi media dalam menyampaikan sebuah berita.

Pamela J. Shoemaker dan Stephen D. Reese (1996), dalam Mediating The Message: Theories of Influences on Mass Media Content, menyusun berbagai faktor yang mempengaruhi pengambilan keputusan dalam ruang pemberitaan. Mereka mengidentifikasikan ada lima faktor yang mempengaruhi kebijakan redaksi dalam

\footnotetext{
24 Bandingkan dengan berita yang dilansir BBC.Com berjudul "Warga Syiah Sampang "Dipaksa Bertaubat" bbc.com, pada 12 Agustus 2013 pada Laman: http://www.bbc.com/indonesia/berita_indonesia/2013/08/130812_pengungsi_syiah_syahadat_ul ang

${ }^{25}$ KH. Lutfi Lah Ridwan, 23 KK Penganut Syiah Kembali ke Aliran Sunni, inilah.com, diakses pada Jumat, 02 November 2012 Pukul 11:49 WIB pada Laman: http://m.inilah.com/news/detail/1922523/23-kk-penganut-syiah-kembali-ke-aliran-sunni. Inilah.com merupakan media nasional yang bekerja sama dengan beritajatim.com. Berita dari reporter beritajatim.com yang dianggal layak untuk dipublikasikan di media nasional ini, maka juga dipublikasikan di media ini, dan demikian juga sebaliknya, karena kedua media tersebut bekerja sama, meski bukan dalam naungan satu badan usaha.
} 
menentukan isi media sebagai berikut ${ }^{26}$, Pertama, Faktor individual. Faktor ini berhubungan dengan latar belakang profesional dari pengelola media. Level indivual melihat bagaimana pengaruh aspek-aspek personal dari pengelola media mempengaruhi pemberitaan yang akan ditampilkan kepada khalayak. Latar belakang individu seperti jenis kelamin, umur, atau agama, dan sedikit banyak mempengaruhi apa yang ditampilkan media. Latar belakang pendidikan, atau kecenderungan orientasi pada partai politik sedikit banyak bisa mempengaruhi profesionalisme dalam pemberitaan media. Kedua, Rutinitas Media, berhubungan dengan mekanisme dan proses penentuan berita. Setiap media umumnya mempunyai ukuran sendiri tentang apa yang disebut berita, apa ciri-ciri berita yang baik, atau apa kriteria kelayakan berita. Ukuran tersebut adalah rutinitas yang berlangsung tiap hari dan menjadi prosedur standar bagi pengelola media yang berada di dalamnya. Rutinitas media ini juga berhubungan dengan mekanisme bagaimana berita dibentuk. Ketika ada sebuah peristiwa penting yang harus diliput, bagaimana bentuk pendelegasian tugasnya, melalui proses dan tangan siapa saja tulisan sebelum sampai ke proses cetak, siapa penulisnya, siapa editornya, dan seterusnya.

Ketiga, Organisasi. Level organisasi berhubungan dengan struktur organisasi yang secara hipotetik mempengaruhi pemberitaan. Pengelola media dan wartawan bukan orang tunggal yang ada dalam organisasi berita, ia sebaliknya hanya bagian kecil dari organisasi media itu. Masing-masing komponen dalam organisasi media bisa jadi mempunyai kepentingan sendiri-sendiri. Di dalam organisasi media, misalnya, selain bagian redaksi ada juga bagian pemasaran, bagian iklan, bagian sirkulasi, bagian umum, dan seterusnya. Masing-masing bagian tersebut tidak selalu sejalan. Mereka mempunyai tujuan dan target masingmasing, sekaligus strategi yang berbeda untuk mewujudkan target tersebut. Bagian redaksi misalnya menginginkan agar berita tertentu yang disajikan, tetapi bagian sirkulasi menginginkan agar berita lain yang ditonjolkan karena terbukti dapat menaikkan penjualan. Setiap organisasi berita, selain mempunyai banyak elemen juga mempunyai tujuan dan filosofi organisasi sendiri, berbagai elemen tersebut mempengaruhi bagaimana seharusnya wartawan bersikap, dan bagaimana juga seharusnya peristiwa disajikan dalam berita.

Keempat, Ekstra media. Level ini berhubungan dengan faktor lingkungan di luar media. Meskipun berada di luar organisasi media, hal-hal di luar organisasi media ini sedikit banyak dalam banyak kasus mempengaruhi pemberitaan media. Ada beberapa faktor yang termasuk dalam lingkungan di luar media: 1). Sumber berita. Sumber berita di sini dipandang bukanlah sebagai pihak yang netral yang memberikan informasi apa adanya, ia juga mempunyai kepentingan untuk mempengaruhi media dengan berbagai alasan: memenangkan opini publik, atau memberi citra tertentu kepada khalayak, dan seterusnya. Sebagai pihak yang mempunyai kepentingan, sumber berita tentu memberlakukan politik pemberitaan. Ia akan memberikan informasi yang sekiranya baik bagi dirinya, dan mengembargo informasi yang tidak baik bagi dirinya. Kepentingan sumber berita ini sering kali tidak disadari oleh media. 2). Sumber penghasilan media, berupa iklan, bisa juga berupa pelanggan/pembeli media. Media harus survive, dan untuk

26 Lihat, Pamela J. Shoemaker dan Stephen D. Reese (1996), dalam Mediating The Message: Theories of Influences on Mass Media Content, Longman Publishers USA. All rights reserved. 
bertahan hidup kadangkala media harus berkompromi dengan sumber daya yang menghidupi mereka. Misalnya media tertentu tidak memberitakan kasus tertentu yang berhubungan dengan pengiklan. Pihak pengiklan juga mempunyai strategi untuk memaksakan versinya pada media. Ia tentu saja ingin kepentingannya dipenuhi, itu dilakukan di antaranya dengan cara memaksa media mengembargo berita yang buruk bagi mereka. Pelanggan dalam banyak hal juga ikut mewarnai pemberitaan media. Tema tertentu yang menarik dan terbukti mendongkrak penjualan, akan terus-menerus diliput oleh media. Media tidak akan menyianyiakan momentum peristiwa yang disenangi oleh khalayak.

Selanjutnya, 3), Pihak eksternal seperti pemerintah dan lingkungan bisnis. Pengaruh ini sangat ditentukan oleh corak dari masing-masing lingkungan eksternal media. Dalam negara yang otoriter misalnya, pengaruh pemerintah menjadi faktor yang dominan dalam menentukan berita apa yang disajikan. Keadaan ini tentu saja berbeda di negara yang demokratis dan menganut liberalisme. Campur tangan negara praktis tidak ada, justru pengaruh yang besar terletak pada lingkungan pasar dan bisnis.

Kelima, Ideologi, diartikan sebagai kerangka berpikir atau kerangka referensi tertentu yang dipakai oleh individu untuk melihat realitas dan bagaimana mereka menghadapinya. Berbeda dengan elemen sebelumnya yang tampak konkret, level ideologi ini abstrak. Ia berhubungan dengan konsepsi atau posisi seseorang dalam menafsirkan realitas.

Sementara itu, Raymond William (dalam eriyanto, 2001) mengklasifikasikan penggunaan ideologi tersebut dalam tiga ranah, yakni pertama, sebuah sistem kepercayaan yang dimiliki oleh kelompok atau kelas tertentu. Definisi ini terutama dipakai oleh kalangan psikologi yang melihat ideologi sebagai seperangkat sikap yang dibentuk dan diorganisasikan dalam bentuk yang koheren. Sebagai misal, seseorang mungkin mempunyai seperangkat sikap tertentu mengenai demontrasi buruh. Ia percaya bahwa buruh yang berdemontrasi mengganggu kelangsungan produksi. Oleh karenanya, demontrasi tidak boleh ada, karena hanya akan menyusahkan orang lain, membuat keresahan, menggangu kemacetan lalulintas, dan membuat persahaan mengalami kerugian besar. Jika bisa memprediksikan sikap seseorang semacam itu, kita dapat mengatakan bahwa orang itu mempunyai ideologi kapitalis atau borjuis. Meskipun ideologi disini terlihat sebagai sikap seseorang, tetapi ideologi di sini tidak dipahami sebagai sesuatu yang ada dalam diri individu sendiri, melainkan diterima dari masyarakat.

Kedua, Sebuah sistem kepercayaan yang dibuat -ide palsu atau kesadaran palsu- yang biasa dilawankan dengan pengetahuan ilmiah. Ideologi dalam pengertian ini adalah seperangkat kategori yang dibuat dan kesadaran palsu dimana kelompok yang berkuasa atau dominan menggunakannya untuk mendominasi kelompok lain. Karena kelompok yang dominan mengontrol kelompok lain dengan menggunakan perangkat ideologi yang disebarkan ke dalam masyarakat, akan membuat kelompok yang didominasi melihat hubungan itu nampak natural, dan diterima sebagai kebenaran. Di sini, ideologi disebarkan lewat berbagai instrumen dari pendidikan, politik sampai media massa. Ketiga, proses umum produksi makna dan ide. Ideologi disini adalah istilah yang digunakan untuk menggambarkan produksi makna. 
Dengan demikian, lima hal itulah yang menjadi pertimbangan, media dan wartawan dalam memproduksi berita konflik antara kelompok Islam Syiah dan Sunni di Sampang, Madura, Jawa Timur tersebut. Media nasional seperti tempo.com dan kompas.com, jelas tidak ada kaitannya dengan jatah kue iklan lokal Pemkab Sampang, sehingga kedua media lebih ekploratif dalam menyajikan informasi, dan tidak menunjukkan keberpihakan kepada salah satu kelompok yang terlihat konflik. Bahkan, kompas.com cenderung menggugat dominatif peran kiai Madura sebagai pengendali konflik dengan menerbitkan berita berjudul "Penyelesaian Konflik Sampang Kuncinya Ada pada Kyai Madura", meski disatu sisi media ini juga berupaya mendiskreditkan kelompok Syiah sebagai biangkerok konflik dengan berita berjudul "MUI Jatim: Kalau Syiah Masih Ada, Tetap Ada Konflik".

Sementara, media lokal madura seperti maduracorner.com dan media regional seperti beritajatim.com, cenderung berpihak kepada kelompok mayoritas, yakni Sunni dan memposisikan Syiah sebagai kelompok sesat, karena keduanya, masih terimat dengan lingkungan sekitar. Tugas wartawan yang kesehariannya di Madura, yakni di Kabupaten Sampang, jelas menjadi pertimbangan tersendiri dalam menjaga keberlangsungan tugas-tugas mereka di masa-masa yang akan datang disamping mempertimbangkan pola kerja sama yang selama ini terbangun, atau yang oleh Pamela J. Shoemaker dan Stephen D. Reese (1996) disebut dengan ektra media.

\section{Kesimpulan}

Ekonomi politik media merupakan istilah yang digunakan secara umum untuk memadukan kerangka teoriti komunikasi dengan kerangka teoritik politik dan ekonomi. Sebagai entitas yang dikonstruksi oleh media, apa yang disebut sebagai komunikasi sering merepresentasikan kepentingan ekonomi sekaligus politik tertentu. Dalam pemberitaan konflik antara kelompok Islam Syiah dan Sunni yang terjadi pada 26 Agustus 2012 di Sampang, Madura, faktor politik, yakni didominasi kelompok mayoritas Sunni, menjadi pertimbangan tersendiri bagi sebagian wartawan dan media lokal untuk menyajikan informasi yang cenderung memihak Sunni disatu sisi dan mendiskreditkan Syiah di sisi lain. Demikian juga keseharian atau lingkungan hidup wartawan, termasuk ideologi yang dianut selama ini.

Setidaknya ada lima faktor yang mempengaruhi kebijakan pemberitaan, baik di kalangan wartawan ataupun di tingkat redaksi dalam menentukan isi media, yakni Faktor individual, rutinitas media, organisasi, ekstra media yang meliputi, 1), sumber berita, 2), Sumber penghasilan media, dan 3), pihak eksternal seperti pemerintah dan lingkungan bisnis. Faktor Kelima, adalah Ideologi, baik ideologi media, ataupun ideologi yang dianut oleh wartawan, sehingga menjadi landasan paradigma dalam menyajikan berita yang hendak dipublikasikan di media tempat ia bekerja.

Berdasarkan hasil kajian dan penelitian para akademisi, sebenarnya konflik Syiah dan Sunni di Sampang itu, karena akibat perbedaan paham dan dikelola sedemikian rupa oleh tokoh-tokoh ulama berpaham Sunni, hingga akhirnya menyebabkan kebencian massal dengan membangun stigma bahwa Syiah sesat. Namun pemerintah setempat dan ulama berupaya mengalihkan fakta itu melalui 
media lokal setempat, sehingga pihak korban, yakni Syiah dianggap sebagai penyebab terjadinya kerusuhan.

\section{Daftar Pustaka}

Adila, Isma. Spasialisasi Dalam Ekonomi Politik Komunikasi (Studi Kasus MRA Media), Jurnal Ilmu Komunikasi, Vol. 1, No.1, 2001.

Ardiyanti, Handrini. Konflik Sampang: Sebuah Pendekatan Sosiologi-Komunikasi. (Politica Vol. 3, No. 2, November 2012)

Dharma, Ferry Adhi. Kritik Terhadap Teori Spiral of Silence: Komunikasi Masyarakat Madura dalam Konflik Sunni-Syiah di Sampang. (INFORMASI Kajian Ilmu Komunikasi Volume 46. Nomor 1. Juni 2016)

Eriyanto, Analisis Framing, Konstruksi, Ideologi, dan Politik, (Yogyakarta: LkiS, 2010)

Hazim, Dampak Sosial dan Psikolososial bagi Pengungsi Pasca-Konflik antara SunniSyiah di Sampang Madura, (Psikologi/ Vol: 3 No. 1 , Januari 2015)

Hilmy, Masdar. The Political Economy Of Sunni-Syiah Conflict In Sampang Madura. (Al-Jami'ah, Vol. 53, No. 1, 2015)

Hodari, Gerakan Politik Syiah-Sunni di Desa Karang Gayam dan Blu'uran Sampang Madura. (Jurnal Review Politik Volume 05, Nomor 02, Desember 2015)

Ida, Rachmah \& Laurentius Dyson, Konflik Sunni-Syiah dan dampaknya terhadap komunikasi intra-religius pada komunitas di Sampang-Madura. (Masyarakat, Kebudayaan dan Politik Vol. 28, No. 1, tahun 2015, hal. 33-49)

Jatim, Telaah Fenomenologis Patrimonalisme Budaya Politik Terhadap Konflik Sunni-Syiah Madura. Maraji: Jurnal Studi Keislaman Volume 3, Nomor 1, September 2016)

McQuail Denis, Teori Komunikasi Massa, (Jakarta: Penerbit Salemba Humanika, Jakarta, 2010)

Morrisan, Teori Komunikasi Massa, (Jakarta: Ghalia Indonesia, 2010)

Mulyono, Slamet. Pergolakan Teologi Syiah-Sunni: Membedah Potensi Integrasi dan Disintegrasi. (Ulumuna Jurnal Studi Keislaman, Volume 16 Nomor 2 (Desember 2012)

Pamela J. Shoemaker et.all, Mediating The Message: Theories of Influences on Mass Media Content, (Longman Publishers USA All rights reserved, 1996).

Qodir, Zuly. Pertentangan dan Pergumulan Syiah di Indonesia dalam Tragedi Sampang. (Jurnal Review Politik Volume 03, Nomor 01, Juni 2013)

Rachmadha, Arnis. The Study of The Second Conflict In Sampang. (Jurnal "Analisa" Volume 20 Nomor 02 Desember 2013 halaman 145-153)

Vincent Mosco, The Political Economy of Communication: Rethinking And Renewal, (London: Sage Publication, 1996).

Wiyata, A. Latief, Carok Konflik Kekerasan dan Harga Diri Orang Madura, (Yogyakarta: PT LKiS Printing Cemerlang, Cetakan II, 2013).

Suryadharma Ali (2012), Solusi Konflik Sampang Versi Pemerintah, tempo.co, diakses 28 Agustus 2012 pada laman: https://nasional.tempo.co/read/426083/solusi-konflik-sampang-versipemerintah 
Suryadharma Ali (2012), Menag: Dialog Solusi Cepat Ricuh Sampang, Madura, tempo.co, diakses 29 Agustus 2012 pada laman: https://nasional.tempo.co/read/426136/menag-dialog-solusi-cepat-ricuhsampang-madura

Hasyim Muzadi (2012), Penyelesaian Konflik Sampang Kuncinya Ada di Kyai Madura, kompas.com diakses pada 1 September 2012 pada laman: https://nasional.kompas.com/read/2012/09/01/14081997/penyelesaian.k onflik.sampang.kuncinya.ada.di.kyai.madura.

Gamawan Fauzi, Mendagri: Konflik di Sampang Bukan Sunni-Syiah, kompas.com, 28 Agustus 2012 pada laman: https://nasional.kompas.com/read/2012/08/28/14502998/Mendagri.Konfl ik.di.Sampang.Bukan.Sunni.Syiah.

KH Abdusshomad Buchori, MUI Jatim: Kalau Syiah Masih Ada, Tetap Ada Konflik, kompas.com, 3 September 2012 pada laman: https://nasional.kompas.com/read/2012/09/03/15355642/MUI.Jatim.Kala u.Syiah.Masih.Ada.Tetap.Ada.Konflik.

KH. Lutfi Lah Ridwan, 23 orang Penganut Syiah Sampang, Kembali Ke Sunni, maduracorner.com, diakses 3 November 2012 pada laman: http://www.maduracorner.com/23-orang-penganut-syiah-sampangkembali-ke-sunni/

BBC, Warga Syiah Sampang "Dipaksa Bertaubat", bbc.com, 12 Agustus 2013 pada Laman:http://www.bbc.com/indonesia/berita indonesia/2013/08/130812 pengungsi syiah syahadat ulang

KH. Lutfi Lah Ridwan, 23 KK Penganut Syiah Kembali ke Aliran Sunni, inilah.com, diakses pada Jumat, 02 November 2012 Pukul 11:49 WIB pada Laman: http://m.inilah.com/news/detail/1922523/23-kk-penganut-syiah-kembalike-aliran-sunni. 